\title{
A Pleistocene amphisbaenian from Sicily
}

\author{
Massimo Delfino
}

Earth Sciences Department and Museum of Natural History (Section of Geology and Paleontology), Florence University, Via La Pira 4, I-50121 Florence, Italy

e-mail: delfino@geo.unifi.it

\begin{abstract}
Recent analysis of the fossil herpetofauna recovered from the latest Middle or earliest Late Pleistocene layers of the site called "K 22" (San Vito Lo Capo, TP, Sicily) revealed the presence of a single vertebra that unquestionably belongs to the order Amphisbaenia. Although it is not possible to assign it at family level, the presence of an undetermined amphisbaenian in the Pleistocene of Sicily represents the last European occurrence of this order outside the present range corroborating the idea that the modern Italian herpetofauna is relatively impoverished if compared to the Pleistocene one, and that this loss of biodiversity not only affected the peninsula but its islands also.
\end{abstract}

\section{Introduction}

The ancient presence of the order Amphisbaenia in Italy has been underestimated for decades but, although non abundant, its fossil record is now richer than that of some groups that still inhabit the area (a list and location of the fossil sites yielding amphisbaenians is given in fig. 1). The first mention of this order in Italy has been published for the Sardinian site of Mandriola (Capo Mannu, OR; Early Pliocene) by Pecorini et al. (1974) who simply listed the presence of undetermined amphisbaenians. For nearly twenty years this has been the only available datum, but starting from the last decade new descriptions have been published. Cavallo et al. (1993) described and figured a dentary coming from the Late Miocene site Ciabòt Cagna (Cornelliano d'Alba, CN, Piedmont) referring it to the family Amphisbaenidae. From karst fissure fillings of the Gargano area (FG, Apulia) amphisbaenians of two different ages have been reported: the extinct genus Palaeoblanus Schleich 1988, from the Late Miocene/Early Pliocene fissures - endemic "terre rosse" or "Microtia fauna" - and the extant genus Blanus from the Early Pleistocene deposits Cava Pirro and Dell'Erba - (Delfino, 1996, 1997, 2002; Delfino and Bailon, 2000). Since the comparative osteology of the living species $B$. cinereus and $B$. strauch $i$ is not known in 


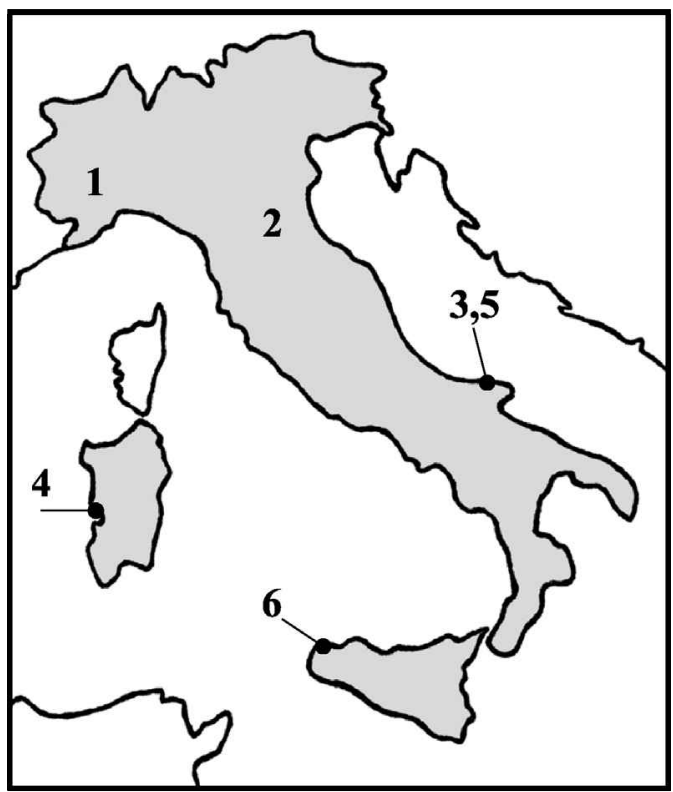

Figure 1. Location map of the Italian amphisbaenian remains:

1) Amphisbaenidae indet.; Ciabòt Cagna, Cornelliano d'Alba (CN); late Miocene (MN 13); Cavallo et al., 1993;

2) Amphisbaenia indet.; Cava Monticino, Brisighella (RA); late Miocene (MN 13); Delfino, 2002;

3) Palaeoblanussp.; Gargano "terre rosse" (FG); late Miocene-early Pliocene; Delfino, 1997; Delfino and Bailon, 2000; Delfino, 2002;

4) Amphisbaenia indet.; Mandriola, Capo Mannu (OR); early Pliocene (MN 14-15); Pecorini et al., 1974; Kotsakis and Palombo, 1979; Esu and Kotsakis, 1983;

5) Blanus sp.; Cava Pirro/Dell'Erba, Apricena (FG); early Pleistocene; Delfino, 1996, 1997; Holman, 1998; Delfino and Bailon, 2000;

6) Amphisbaenia indet.; K 22, San Vito Lo Capo (TP); latest middle-earliest late Pleistocene; Delfino, 2002, this paper.

detail, the Pleistocene remains have been simply allocated to genus level, even if they most likely belong to one of them. Holman (1998) erroneously quoted these remains as Blanus cf. B. strauchi. Undetermined amphisbaenian vertebrae have been recently found in the Late Miocene of Cava Monticino(Brisighella, RA, Emilia-Romagna; Delfino, 2002) and in the Middle/Late Pleistocene site called "K 22" (San Vito Lo Capo, TP, Sicily). The isolated vertebra coming from the latter site (already figured and briefly commented by Delfino, 2002 ) is the object of this short contribution to the history of the Italian herpetofauna.

\section{Material and methods}

The "K 22" fossil fauna has been recovered in 1994 during fieldwork held by Prof. Federico Masini and coworkers. The material here considered comes from the "pelitic rubefyed horizon" (paleosol F) described by Di Maggio et al. (1999): the associated fauna includes elements of the Sicilian "Elephas mnaidriensis" Faunal Complex and can be therefore referred to the latest Middle or earliest Late Pleistocene. 
The described vertebra is presently deposited (with the inventory number K22/R/1) in the collections of the Museum "G.G. Gemmellaro" in Palermo (Geology and Geodesy Department of the Palermo University). The pencil drawings have been realised on a Wild M 8 stereo microscope connected with a Wild TYP 308700 camera lucida.

\section{Systematic part}

\section{Order Amphisbaenia Gray 1844}

Amphisbaenia indet.

\section{Material: One vertebra.}

Description: The fossil vertebra is perfectly preserved with the exception of the anterior part of the prezygapophysesthat are broken off. The centrum is procoelous and it measures $1.7 \mathrm{~mm}$ from the ventral edge of the cotyle to the posterior tip of the condyle.

In dorsal view (fig. 2A), the vertebra shows a marked median constriction; the remnants of the prezygapophyses are antero-laterally directed; the anterior edge of the neural arch is strongly convex and rounded, while the posterior one describes a wide concavity with a hardly visible median tip; the posterior area of the neural arch is nearly flattened; two very small ridges run parasagittally to the neural crest.

In ventral view (fig. 2B), the surface of the vertebral body is flat and laterally delimited by slightly concave and subparallel margins; two nearly symmetric foramina open in the
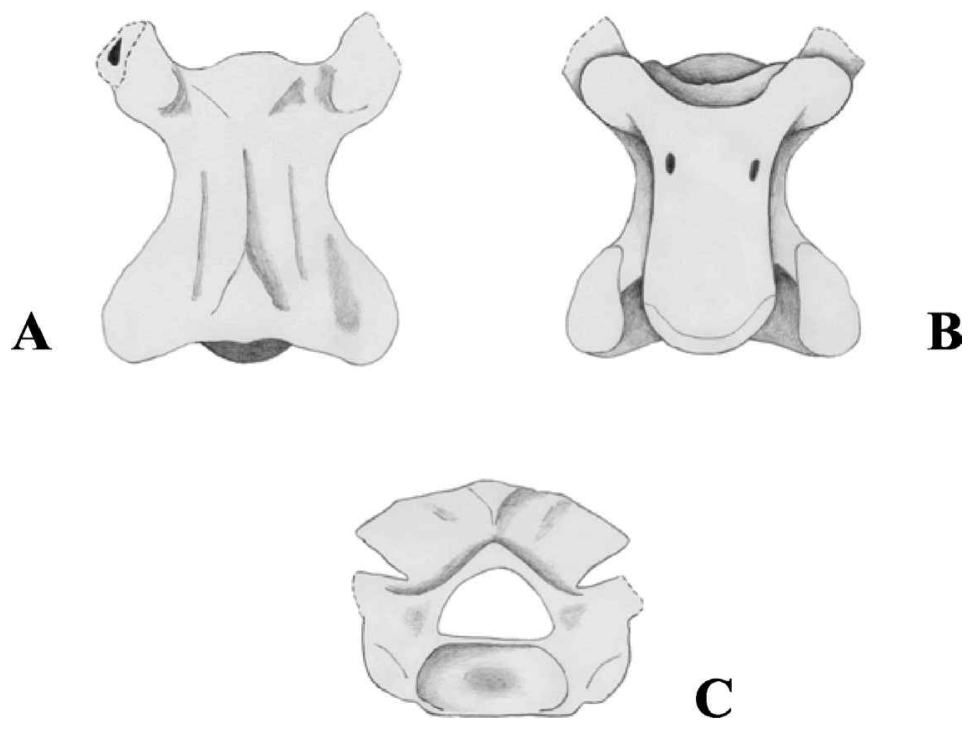

Figure 2. Amphisbaenia indet., trunk vertebra, K 22; San Vito Lo Capo (TP), Sicily. A - dorsal view; $\mathrm{B}$ - ventral view; $\mathrm{C}-$ anterior view. The scale bar is equal to $2 \mathrm{~mm}$. 
middle of the anterior part of the ventral surface; no hypapophysis, keels or grooves are perceivable on the ventral surface; the dorsal margin of the cotyle slightly overhangs the ventral one, while the anterior margin of the neural arch overhangs both; diapophyses and parapophyses are fused in protruding ovoid synapophyses; the remaining portion of the prezygapophyses is too posterior to preserve the prezygapophyseal processes (that in amphisbaenian are rather short and massive); the postzygapophyseal facets are dropshaped.

In anterior view (fig. 2C), the neural arch is convex and devoid of zygosphene; the cotyle is strongly dorso-ventrally compressed, being approximately two times wider than high; the neural canal is approximately triangular; the prezygapophysealfacets are dorsally tilted.

In posterior view, the neural arch is moderately vaulted and devoid of zygantrum; the condyle is dorso-ventrally compressed, similarly to the cotyle.

In lateral view, the neural spine is underdeveloped and represented by a small crest; the upper profile of the neural arch is concave.

Taxonomic allocation: All the described characteristics perfectly match with the general description of an amphisbaenian vertebra: procoelous, neural spine reduced or absent, zygosphene-zygantrum absent, vertebral body ventrally flattened with subparallel or slightly concave margins (Zangerl, 1945; Bailon, 1991). The presence of prezygapophyseal processes, that along with the above listed features characterise this group, cannot be checked. The absence of hypapophysis (typical of cervical vertebrae) or haemapophyses and transverse processes (typical of cloacal and caudal vertebrae) clearly identify the vertebra as a trunk one.

Since the isolated vertebrae of amphisbaenians are not diagnostic not only to genus but even to family level (Estes, 1983), the amphisbaenian vertebra from Sicily should be simply referred to "Amphisbaenia indeterminate". Nevertheless, the presence of an undetermined member of this group of reptiles in the Middle or Late Pleistocene of Sicily is rather surprising and stimulates some reflections on its origin and on the evolution of the Italian herpetofauna.

\section{Discussion}

Unexpectedly, some Neogene, as well as some Pleistocene Italian localities that yielded microvertebrate remains, host amphisbaenians usually represented by isolated vertebrae and in some cases also by highly informative cranial elements. The relatively recent discovery of these reptiles in Italy appears to reflect the former lack of interest of paleontologists and the very small size of the amphisbaenian remains which makes their recovery difficult.

Delfino (1997) summarised the Cenozoic European occurrence of fossil amphisbaenians, showing a progressive range reduction from the northern part of the continent to the 
southern Peninsulas. Up to the Miocene, their range covered the entire Central and Western Europe (Great Britain included), but the post-Miocene findings are all located near the Mediterranean Sea or inside the modern range (restricted to the Iberian Peninsula). The presence of Blanus in the Early Pleistocene of Southern Peninsular Italy suggests that its range was continuous along the Northern Mediterranean border, as argued by Alexander (1966). The absence of fossil remains in Eastern Europe, especially from the Balkan Peninsula, is rather striking and could be due to the scarcity of paleoherpetological investigations in the area or to a real gap in their ancient range.

The first hypothesis (lack of data) is strengthened by the fact that during part of the Neogene the Gargano area (that hosted amphisbaenians) was in connection to the Dalmatic area (among others: De Giuli et al., 1986): even if the west Balkan faunas are still poorly known, a certain degree of faunal affinity between the Apulian and the Dalmatic areas can be predicted.

The latter hypothesis (presence of gap) seems to be supported by the contrast between the presumed extinction of amphisbaenians from the Balkans and the role of this region as a refugium for taxa that once inhabited a larger part of Europe (among reptiles: agamids, Pseudopus, scolecophidians, Eryx and large vipers of the so-called “oriental group").

Worm lizards probably arrived in Sicily through southward dispersal from mainland Italy (because Blanus is present in the Early Pleistocene of Apulia) even if a northward dispersion from Africa cannot be excluded a-priori. In any case, the fossorial habits of amphisbaenians seem to limit their rafting (Busack, 1986) or drifting capabilities suggesting a dispersal via land bridges. Di Maggio et al. (1999) and Masini et al. (2002) pointed out that the macromammals of the E. mnaidriensis Faunal Complex (from which the amphisbaenian vertebra comes) show a moderate endemism and derive from dispersal events of European origin whereas the micromammals are forms derived from the preceding highly endemic Faunal Complex (E. falconeri F. C.) that dated to the first part of the Middle Pleistocene.

It is still not known whether Sicily had connections with North Africa during the Middle Pleistocene (Agnesi et al., 1998; Bonfiglio et al., 1999) and, therefore, whether the origin of the Elephas falconeri F. C. of the "siculo-maltese" archipelago is, at least partially, connected with northward dispersals of African elements. However, it has to be underlined that the giant tortoises discovered in two areas of Sicily (Testudininei indet.; Middle Pleistocene; Burgio and Cani, 1988; Delfino, 2002) can be reasonably considered phylogenetically related to those described from Malta (Leith-Adams, 1887) even only on a biogeographic basis (they all belong to the same Faunal Complex). Since giant tortoises are not known in Pleistocene continental Europe, it could be hypothesised that they came from North Africa via land-bridges or with the aid of favourable sea currents, being preadapted for drifting and successful sea dispersal (see Pritchard, 1996, for a discussion). This is plausible because Centrochelys (= Geochelone) remains have been reported in the Quaternary of Algeria and Egypt (de Lapparent de Broin, 2000). Further analysis and comparisons of the Maltese and Sicilian giant tortoises as well as the North African coeval 
chelonians could contribute to find evidences of these (phylogenetic but not necessarily geographic) connections.

If a North African origin of the Sicilian amphisbaenian were confirmed, they could belong to the family Trogonophidae and not Amphisbaenidae because the former family is the only one that reaches Tunisia at present (with the species Trogonophis wiegmanni), the latter being restricted to Morocco (Schleich et al., 1996).

Whatever the origin may be for the Sicilian amphisbaenian, it is remarkable that during the Pleistocene the island hosted, along with representatives of the modern herpetofauna (Discoglossus, Bufo, Rana, Testudo, Emys, Tarentola, Podarcis, Hierophis, Natrix, Vipera), also taxa that are now locally or definitely extinct: the described amphisbaenian, the giant tortoises of the Alcamo and the Ragusa area, and large-sized lacertid lizards formerly referred to the extinct species Lacerta siculimelitensis Böhme and Zammit-Maempel 1982 but whose relationships with Timon should be taken into considerations (Delfino, 2002). If the presence of the giant tortoises and large-sized lizards might be somehow linked to the evolution in an insular environment (these taxa are not known in coeval continental areas), the occurrence of the last Italian amphisbaeniansin Sicily (assuming a non-African origin), could be an example of prolonged survival, and therefore delayed extinction, in an insular refugium, in accordance with what has already been reported for some mammals.

Although the Sicilian climate and environments during the last glacial cycles have never been investigated in detail, it is possible that they were not so different from those of the Peninsula but that the African influx increased aridity during the interglacials and mitigated the colder phases (Agnesi et al., 1998). These conditions could have favoured long-term survival of thermophilous and xerophilous reptiles. Modern populations of Blanus cinereus perfectly match these requirements since this species "prefers relatively dry and thermally favourable habitats, on slopes with a good exposure to the sun" (Gil, 1997).

The southern European Peninsulas have been traditionally seen as cold stage refugia for many plants and animal taxa (among others: Bennet et al., 1991; Hewitt, 2000) but concerning the herpetofauna, the role of Italy appears to be contradictory. An overview should take into consideration that some taxa that are still present in the Balkans (agamids and large vipers) or in Anatolia (monitor lizards and soft-shell turtles) disappeared from the Italian peninsula during the Neogene and others that are still present in Iberia (amphisbaenians), in the Balkans (Pseudopus, Eryx) or both (Mauremys), disappeared during the Pleistocene.

Even if this is in contrast with the fact that it still hosts the genus Salamandrina (whose fossils have been found in Greece; Vanni and Nistri, 1997), Italy seems to have been, at least for reptiles, a refugium not as comfortable as the two other Mediterranean Peninsulas of Europe.

Acknowledgements. The material has been studied thanks to the courtesy of the staff of the Museum "G.G. Gemmellaro" in Palermo (Geology and Geodesy Department of the Palermo University). Federico Masini raised 
my curiosity about the evolution of the Sicilian faunas patiently discussing, through the years, insular dynamics. Marc Cheylan critically commented upon the manuscript suggesting a vast number of ideas that will be the object of a future paper. Daria Petruso offered logistic and practical assistance during my work in Palermo. Günter Gollmann, as well as the anonymous reviewers, provide helpful criticism.

\section{References}

Agnesi, V., Macaluso, T., Masini, F. (1998): L'ambiente e il clima della Sicilia nell'ultimo milione di anni. In: Prima Sicilia. Alle origini della società siciliana (vol. 1), p. 31-56. Palermo, Ediprint.

Alexander, A.A. (1966): Taxonomy and variation of Blanus strauchi (Amphisbaenia, Reptilia). Copeia 1966 (2): 205-224.

Bailon, S. (1991): Amphibiens et reptiles du Pliocène et du Quaternaire de France et d'Espagne: mise en place et évolution des faunes. Doctoral Thesis, Univ. Paris VII.

Bennet, K.D., Tzedakis, P.C., Willis, K.J. (1991): Quaternary refugia of north European trees. J. Biogeogr. 18: 103-115.

Bonfiglio, L., Marra, A.C., Masini, F. (1999): The contribution of Quaternary vertebrates to palaeonvironmental and palaeoclimatological reconstructions in Sicily. In: Climates: Past and Present, p. 171-184. Hart, M.B., Ed., Geological Society, London, Special Publications, 181.

Burgio, E., Cani, M. (1988): Sul ritrovamento di elefanti fossili ad Alcamo (Trapani, Sicilia). Naturalista sicil., S. 4, 12(3-4): 87-97.

Busack, S.D. (1986): Biogeographic analysis of the herpetofauna separated by the formation of the Strait of Gibraltar. National Geographic Research 2: 17-36.

Cavallo, O., Sen, S., Rage, J.C., Gaudant, J. (1993): Vertébrés messiniens du faciès à Congéries de Ciabòt Cagna, Cornelliano d'Alba (Piémont, Italie). Riv. Piem. St. Nat. 14: 3-22.

De Giuli, C., Masini, M., Torre, D., Valleri, G. (1986): Mammal migration events in emerged areas of the Apulian platform during the Neogene. Giornale di Geologia, ser. 3, 48: 145-162.

Delfino, M. (1996): Erpetofauna Tardo Villafranchiana di Cava Dell'Erba e Cava Pirro (Foggia, Puglia, Italia). Unpublished dissertation thesis, Turin University, Italy.

Delfino, M. (1997): Blanus from the Early Pleistocene of Southern Italy: another small tessera from a big mosaic, p. 89-97. Böhme, W., Bischoff, W., Ziegler, T., Eds, Herpetologia Bonnensis, Bonn, Societas Europaea Herpetologica.

Delfino, M. (2002): Erpetofaune italiane del Neogene e del Quaternario. Unpublished doctoral thesis, Modena and Reggio Emilia University, Italy.

Delfino, M., Bailon, S. (2000): Early Pleistocene herpetofauna from Cava Dell'Erba and Cava Pirro (Apulia, Southern Italy). Herpetological Journal 10: 95-110.

Di Maggio, C., Incandela, A., Masini, F., Petruso, D., Renda, P., Simonelli, C., Boschian, G. (1999): Oscillazioni eustatiche, biocronologia dei depositi continentali quaternari e neotettonica nella Sicilia Nord Occidentale (Penisola di San Vito Lo Capo - Trapani). Il Quaternario (It. J. Quaternary Sciences) 12(1): 25-50.

Estes, R. (1983): Sauria terrestria, Amphisbaenia. In: Handbuch der Paläoherpetologie, vol. 10A. Stuttgart/New York, Gustav Fischer Verlag.

Esu, D., Kotsakis, T. (1983): Paleobiogeografia dei vertebrati e dei molluschi continentali del Terziario e del Quaternario della Sardegna. Lavori Soc. Ital. Biogeogr., n. s., 8 (1980): 53-83.

Gil, M.J. (1997): Blanus cinereus (Vandelli, 1797). In: Distribucion y biogeografia de los anfibios y reptiles en España y Portugal, p. 184-186. Pleguezuelos, J.M., Ed., Granada, Monografías de Herpetología, Volumen 3. Universidad de Granada and Asociación Herpetológica Española.

Hewitt, G. (2000): The genetic legacy of the Quaternary ice ages. Nature 405: 907-913.

Holman, J.A. (1998.): Pleistocene amphibians and reptiles in Britain and Europe. Oxford Monogr. Geol. Geophys. No. 38. New York, Oxford Univ. Press.

Kotsakis, T., Palombo, M.R. (1979): Vertebrati continentali e paleogeografia della Sardegna durante il Neogene. Ann. Géol. Pays Hell., Tome Hors série 2: 621-630.

Lapparent De Broin De, F. (2000): African chelonians from the Jurassic to the Present: phases of development and preliminary catalogue of the fossil record. Paleont. afr. 36: 43-82. 
Leith-Adams, A. (1887): On gigantic land-tortoises and a small freshwater species from the ossiferous caverns of Malta, together with a list of their fossil fauna; and a note on chelonian remains from the rock-cavities of Gibraltar. Quartar J1. Geol. Soc. Lond. 33: 177-191.

Masini, F., Bonfiglio, L., Petruso, D., Marra, A.C., Abbazzi, L., Delfino, M., Fanfani, F., Torre, D. (2002): The role of coastal areas in the Neogene - Quaternary mammal island populations of the central Mediterranean. Biogeographia 23: 165-189.

Pecorini, G., Rage, J.C., Thaler, L. (1974): La formation continentale de Capo Mannu, sa faune de vertébrés pliocènes et la question du Messinien en Sardaigne. Rend. Sem. Fac. Sci. Univ. Cagliari 43 (suppl.): 305-319.

Pritchard, P.C.H. (1996): The Galapagos Tortoises. Nomenclatural and survival status. Chelonian Research Monograph $\mathrm{N}^{\circ}$ I, Chelonian Research Foundation.

Schleich, H.H., Kästle, W., Kabisch, K. (1996): Amphibians and Reptiles of North Africa. Koenigstein, Koeltz Scientific Books.

Vanni, S., Nistri, A., (1997): Salamandrina terdigitata (Lacepède, 1788). In: Atlas of Amphibians and Reptiles in Europe, p. 70-71. Gasc, J.-P., Cabela, A., Crnobrnja-Isailovic, J., Dolmen, D., Grossenbacher, K., Haffner, P., Lescure, J., Martens, H., Martinez Rica, J.P., Maurin, H., Oliveira, M.E., Sofianidou, T.S., Veith, M., Zuiderwijk, A., Eds, Paris, Societas Europaea Herpetologica and Museum National d'Histoire Naturelle.

Zangerl, R. (1945): Contributions to the osteology of the post-cranial skeleton of the Amphisbaenidae. Amer. Midl. Naturalist 33: 764-780.

Received: November 4, 2002. Accepted: January 2, 2003. 